Canadian University Music Review

Revue de musique des universités canadiennes

\author{
Judith Tick. Ruth Crawford Seeger: A Composer's Search for \\ American Music. New York and Oxford: Oxford University \\ Press, 1997. xiv, 457 pp. ISBN 0-195-06509-3 (paperback)
}

\title{
Austin Clarkson
}

Volume 22, numéro 2, 2002

URI : https://id.erudit.org/iderudit/1014510ar

DOI : https://doi.org/10.7202/1014510ar

Aller au sommaire du numéro

Éditeur(s)

Canadian University Music Society / Société de musique des universités canadiennes

ISSN

0710-0353 (imprimé)

2291-2436 (numérique)

Découvrir la revue

Citer ce compte rendu

Clarkson, A. (2002). Compte rendu de [Judith Tick. Ruth Crawford Seeger: A Composer's Search for American Music. New York and Oxford: Oxford University Press, 1997. xiv, 457 pp. ISBN 0-195-06509-3 (paperback)]. Canadian University Music Review / Revue de musique des universités canadiennes, 22(2), 127-131. https://doi.org/10.7202/1014510ar

All Rights Reserved (C) Canadian University Music Society / Société de musique des universités canadiennes, 2003
Ce document est protégé par la loi sur le droit d'auteur. L’utilisation des services d'Érudit (y compris la reproduction) est assujettie à sa politique d'utilisation que vous pouvez consulter en ligne.

https://apropos.erudit.org/fr/usagers/politique-dutilisation/ 


\section{BOOK REVIEWS/RECENSIONS}

Judith Tick. Ruth Crawford Seeger: A Composer's Search for American Music. New York and Oxford: Oxford University Press, 1997. xiv, 457 pp. ISBN 0-195-06509-3 (paperback). ${ }^{1}$

By 2001, when the centenary of the birth of Ruth Crawford Seeger was celebrated far and wide, her presence in the front rank of twentieth-century composers was assured. A large part of the increased understanding and knowledge of the composer was the work of Judith Tick, whose editions of the music and superb biography have done so much to form our knowledge and understanding of Crawford's life and creative gifts.

Tick had a remarkably challenging task, for in a dictionary of musical biography there could really be two entries, one for Ruth Crawford and the other for Ruth Seeger. The career divides so readily down the middle that to keep both halves in focus, as Tick has done, is a major achievement. Ruth Crawford was endowed with exceptional gifts as a performer, composer, teacher, and writer, and was already a ranking avant-garde composer before she met Charles Seeger in 1929. She was his student, then collaborated with him in writing a book, before they were married in 1932. As Ruth Seeger she took on several more occupations-wife, mother (three children from Charles's first marriage and four of their own), piano teacher (to keep the family above the poverty line), folklorist, and author (several editions of folksongs). Ruth's indomitable spirit led her to believe that she could do it all if she only could work hard enough. She worked beyond hard, but the anticipated return to composing concert music was foreclosed when cancer struck her swiftly down in 1953. The need and desire to be Ruth Crawford was a haunting pressure through her life as Ruth Seeger. That she created a life as Ruth Crawford Seeger must be counted as one more of her accomplishments.

Charles Seeger was a polymath with a handful of careers in his own right-composer, theorist, comparative musicologist, teacher, philosopher, folklorist, and administrator. But he did not have the knack of turning his abundant gifts into a living for his large family. Though recognition was long delayed, he lived to glimpse it by the time he died in 1979 aged 93. That Ruth and Charles found each other was more than a domestic romance, for their professional lives took shape in ways that were products of their combined talents and interests. Her gifts as a composer and his intellectual gifts combined in their writing a book on dissonant counterpoint. Their work together as folklorists resulted in editions of folksongs for the general reader that are still

I A review of this book appeared in CUMR 20/2 (2000) by Lori Burns. This review is included to add to the important discussion of Ruth Crawford Seeger. - ED. 
models of scholarly precision and sensitive arrangements. In addition to publications their collaboration extended to the next generation, with three of their children taking up the cause of the folksong revival and bringing traditional musics into the classrooms, living rooms, and concert spaces of the nation.

Tick weaves a life story with many layers and facets. Combining biography with intellectual, musical, and cultural history demands a sophisticated command of resources. Monographs on such composers often take a documentary approach, with extensive verbatim quotations from the composer's memoirs and interviews with friends, relatives, and colleagues. Passages of connecting commentary are penned by the compiler-author. Tick opts for the more challenging method of maintaining a single voice throughout. Quotations of phrases and sentences are folded smoothly into the text, with block quotations seldom more than ten lines long. Her voice ranges as needed from the incisive to the sympathetic, the descriptive to the critical. She is a helpful and assured guide, and the book is a continual pleasure to read.

With such a wealth of documentation to draw on, Tick sketches in the historical background often with a pregnant anecdote rather than with straight description. When Crawford goes to Berlin on a Guggenheim Fellowship in September of 1930, Tick sets the scene of the waning Weimar Republic with a short paragraph that begins: "Germany's political life mirrored the economic chaos. National elections on September 14, 1930, gave the Nazi Party its first great electoral victory; its increase from 12 to 125 seats in the Reichstag made it the second most powerful political party in Germany" (p. 142). Rather than continue with more historical facts and figures, she turns to Bruno Walter's memoirs, when he recalls listening to the election returns with the cellist Emmanuel Feuermann until three in the morning. "Feuermann, usually so gay, left us with the words, 'It's all over with Germany; all over with Europe.'" Tick closes with: "An unsuspecting Ruth Crawford arrived ten days later, on September 24, at the beginning of the end of 'the great days of Berlin."' The scene of the vigil of the two musicians, the mood changing from gay to sombre, is enough to set the scene for Crawford's year in Berlin.

The heart of the story is the struggle of a woman with an extraordinary musical intelligence to find her own way and to be received, recognized, and respected in an era when the ultimate accolade for a woman composer was that she writes like a man. Crawford came from a fundamentalist Christian culture in which the woman's place was in the home, and the arts and letters, and even flowers in the vegetable garden, were "superfluities." Ruth and her mother both were daughters of Methodist ministers for whom hymn singing was the only music permissible. But fundamentalism bred strong resistance in these resilient women, and the arts became a path of liberation. Ruth's mother, Clara, broke the trail for her daughter by entering the work force and achieving a measure of financial autonomy. While Clara was unable to begin piano studies until her late teens, she saw to it that her daughter received instruction at a much younger age. Tick avoids making anachronistic moral judgments, but lays out the ethical 
problems her protagonists faced in the context of their values, all the while keeping in mind her own post-feminist perspective.

Flashbacks and flashforwards lighten the chronological tread and ensure that the portrait of the two Ruths is well-unified. A fine balance between background and foreground anchors and frames the anecdotes and personal documents that keep the story moving. Insightful formulations interpret events with an authorial voice that is both critically observant and sensitively present. Tick assesses Crawford's psychological development without falling into inappropriate diagnosis. Ruth's father died when she was twelve, leaving the family homeless and forcing her mother to run a boarding house. Tick interprets: "Idolizing a father she knew only as a child marked her with a great, perhaps exaggerated respect for missionary fervour." Hearing and reading her father's sermons "accustomed her to the power of the word as public performance and persuasion and to the voice of masculine authority." Having to give up their home, "Ruth suffered a loss that she would attempt to repair as an adult when reestablishing a sense of place for herself. One of her closest women friends from her adult life would later mark the 'transcendental importance' that Ruth attached to her own home, which has its roots in this period of mourning and displacement" (p. 10). Tick in this way gathers opinions from friends and relatives but does not shrink from her own interpretations.

Crawford received a remarkably fine education during her eight years at the American Conservatory in Chicago. She made brilliant progress under a series of teachers, culminating in the Canadian-born pianist, Djane Lavoie-Herz, and the German-born composer, Adolf Weidig. Though trained under Brahms and Riemann, Weidig was tough but liberal and did not patronize his women students: "Weidig defended standards of excellence that enabled Crawford and other talented women to flourish" (p. 38). He inspired Crawford with his dedication and allowed her to follow her intuition and did not prevent her from experimenting with non-tonal procedures. Born in Toronto in 1888 (Ottawa in 1889, according to the Encyclopedia of Music in Canada), Lavoie-Herz studied in Europe, where she came under the influence of Scriabin and his theosophical aesthetics. She returned to Toronto to concertize and teach, and then moved to Chicago. Lavoie-Herz imbued Crawford with the Scriabin aesthetics from which she formed her own "aesthetic theology." Dane Rudhyar, who was a friend of Lavoie-Herz, supported Ruth in this endeavour. Tick does not evade the issue of a spiritualist aesthetics and shows clearly how Crawford embodied it in a "post-tonal" idiom. Crawford found her own path. Unlike Scriabin and Rudhyar, Crawford avoided descriptive titles: "A program as she saw it was a point of departure for the composer, rather than a representational guidepost for the listener" (p. 77).

Though East coast intellectuals, including Charles Seeger, belittled Chicagoan culture, Crawford received an education that was probably more progressive and freer of prejudice against women composers than she would have found had she decided to go to New York or Boston. It would be interesting to look further into the possible impact of the educational theories of John Dewey on Crawford's career as a teacher, for Crawford may well have benefited from 
the concepts of progressive education developed in the laboratory school that Dewey founded at the University of Chicago. Another interesting side-bar on the Chicago years would be to scan for the influence of Bernhard Ziehn, whom Ferruccio Busoni met in Chicago in 1910 and from whom he learned a version of dissonant counterpoint that he applied in the Fantasia Contrappuntistica. The resonances between the spiritualist aesthetics of Busoni, which had such impact on Otto Luening, Edgard Varèse, and Stefan Wolpe, and that of the Chicagoans would also be worth further exploration.

The desire of American artists to carve out a space for themselves was a necessary struggle for liberation from the oppressive dependence of American society on the European tradition. But there are intriguing parallels between experimental and progressive ideas of Americans and Europeans that may illuminate the deeper levels of the human spirit in its quest to find new forms of expression for the modern world. The desire for a new kind of time-space in which musical images break free from the harmonic forces of tonality and the linear forces of thematicism marks Crawford's music of the twenties. Seeger's remarks on Crawford's music of the twenties were severe: "too diffuse, too much reliance upon Scriabinian harmony ... imitative-the curse of the woman composer, always to follow, never to lead" (p. 117). But then he did not approve fully of any composer and his hyper-critical stance blocked his own creativity. He did not think that the music of his friend Carl Ruggles was entirely successful, and he thought Varèse was "a very poor composer." The constraints of Seeger's theory of diaphony (systematically "dissonating" all musical parameters) seem to have reined in Crawford's earlier explorations. Though her music as Ruth Crawford Seeger was still superb, it did not fulfill the earlier promise of a non-linear, non-local, more surrealist and constellatory time-space.

Crawford knew that the demands of becoming a wife and mother would limit her career as a composer. The "woman's dilemma" of combining work and marriage was a common theme in the twenties. The crisis hit at the MacDowell Colony in the summer of 1929, when Crawford fell deeply in love with a young poet. In the confusion of awakening sexuality and knowledge that she was at a crossroads, she pondered her options between "a career or life." She speculated that if she were ever to compose large works like symphonies, she would have to sacrifice having a family and children. Tick concludes the account of the Chicago years with a passage from Crawford's diary as she suffered through her dark night of the soul. The section closes with the simple sentence: "A month later she promised the Guggenheim Foundation a symphony as her new work" (p. 101). Having made a decision on behalf of her career, Crawford went to New York and met Charles Seeger. She never did write a symphony. Tick declares that Crawford was the victim of a false dichotomy between love and work, the "virus" of the notion of separate spheres between female and male creativity, where males write symphonies and females, if married, write smaller pieces (p. 99). And yet Crawford eventually built the writing of small pieces (namely, transcriptions and arrangements of many hundreds of folksongs) into a major work, which, while not symphonic, became an enduring 
part of the culture. Crawford based her books on transcriptions of songs recorded by particular singers at a certain time and place, and not on some homogenized collation of versions. She thus raised the individual singer's version to the status of an original work of art. Tick describes Crawford's exacting process of transcription and how she composed elegantly modern yet simple arrangements. In bringing the traditional music of America to the attention of a wider public, she was not interested in turning it into art songs, as was the custom. But her arrangements for the general audience were works of art nonetheless, as they could have been done only by a highly skilled composer. "She gave the process of transcription a life of its own by connecting to the agency of both the singer and the song, dignifying the mediating process into a discipline all its own" (p. 279). The "American music" of the book's title was rudely denied what would surely have been memorable symphonic works by Ruth Crawford, but it was given a plentiful supply of fine folksongs by Ruth Crawford Seeger. This raises the question of the status of the arrangement, which only now is becoming acceptable again as an art form. We can be sure that Ruth Crawford's symphony would not have included any quotations of folksongs. Her concert music depended for its Americanness on deconstructing characteristic traits of vernacular music and reconstituting them in the fabric of her fantasy. The Wind Quintet she completed the year before she died was her first piece of concert music for many years and it thoroughly revived her. It was a claim for her identity as Ruth Crawford. "The suite reverted to her Chicago style in her pre-Seeger days (and he did not like it much)" (p. 316). And yet she wanted her music now to be under the hyphenated name of "Crawford-Seeger." Henry Cowell, who had supported her from her early years in Chicago, was disappointed to see that she could no longer compose without Charles. Tick concludes that Crawford succumbed to the social gender codes for American women. "Perhaps she adopted the hyphenated form of her name at this point in her career to preserve the equilibrium in her marriage and to reaffirm the vows of creative partnership on which it was founded" (p. 321).

The relationship of Ruth and Charles must be counted as one of their many achievements, missteps, failings, and all. She evidently adored having children and making a home, but her numerous creative projects got in the way of her giving the children all the attention they needed. Charles was a poor provider and yet expected the home and family to be run by Ruth and partly financed by her endless round of giving piano lessons. The consensus was that Ruth for whatever reason was overly accommodating to Charles. Tick steers an even course between compassionate empathy for their struggle to make a life together and dispassionate commentary on how they attempted to negotiate the gender politics of their household, the pressing demands of their exceptional creative gifts, and their respective brushes with depression. There is a Henry Jamesian quality to the story, but Tick does not overplay the dark caste. We see the ups and downs of Crawford's life through the lens of her own spirit as much as through the eyes of those around her. It's a wonderful, admirable spirit, and we are given a nuanced portrait of an extraordinary human being. 